\title{
Does nitrogen availability have greater control over the formation of tropical heath forests than water stress? A hypothesis based on nitrogen isotope ratios
}

\author{
Francis Q. BREARLEY ${ }^{1,2}$, Paul V. A. FINE ${ }^{3}$, Kristel PERREIJN ${ }^{4}$
}

\section{ABSTRACT}

Global scale analyses of soil and foliage $\delta^{15} \mathrm{~N}$ have found positive relationships between $\delta^{15} \mathrm{~N}$ and ecosystem $\mathrm{N}$ loss (suggesting an open $\mathrm{N}$ cycle) and a negative relationship between $\delta^{15} \mathrm{~N}$ and water availability. We show here that soils and leaves from tropical heath forests are depleted in ${ }^{15} \mathrm{~N}$ relative to 'typical' forests suggesting that they have a tight $\mathrm{N}$ cycle and are therefore limited by $\mathrm{N}$ rather than by, often suggested, water availability.

KEYWORDS: acid soils, kerangas, nitrous oxide, stable isotopes

\section{Tem a disponibilidade de nitrogênio maior controle sobre a formação de florestas tropicais de campinara do que o estresse hídrico? Uma hipótese fundamentada nas razões isotópicas do nitrogênio}

RESUMO:

Análises de $\delta^{15} \mathrm{~N}$ solo e foliar, em escala global, encontraram relaçóes positivas entre $\delta^{15} \mathrm{~N}$ e a perda de $\mathrm{N}$ do ecossistema (sugerindo um ciclo aberto de $\mathrm{N}$ ), e uma relação negativa entre o $\delta^{15} \mathrm{~N}$ e a disponibilidade de água. Mostramosneste trabalho que os solos e a vegetação de florestas de campinarana são empobrecidas em ${ }^{15} \mathrm{~N}$ em relação a florestas 'típicas', sugerindo que elas têm um ciclo fechado de $\mathrm{N}$ e são, desta forma, limitadas pelo $\mathrm{N}$, ao invés da disponibilidade de água, como frequentemente sugerido.

PALAVRAS-CHAVE: solos ácidos, campinarana, óxido nitroso, isótopos estáveis.

1 Trinity College, University of Dublin

2 Manchester Metropolitan University E-mail: f.q.brearley@mmu.ac.uk

${ }^{3}$ University of California, Berkeley E-mail: paulfine@berkeley.edu

${ }^{4}$ Utrecht University E-mail: kristelperreijn@yahoo.com 
Determining the factors that lead to differing species distributions in tropical forests, especially in relation to soil type, has been an important question in tropical ecology for many years and still remains a contemporary problem (Fine et al. 2004; Russo et al. 2005). Tropical heath forests (HFs) (also known as white sand forests in the Neotropics) are a formation that are very different to 'typical' lowland evergreen rain forests (LERFs) having more acidic soil, lower stature, a more even canopy, thicker smaller leaves and a greater proportion of trees in smaller size classes (Brünig 1974; Proctor 1999). There are a number of lines of evidence that suggest HFs have lower nitrogen $(\mathrm{N})$ availability than LERFs. For example, Turner et al. (2000) found lower foliar $\mathrm{N}$ in a range of species from HFs in Brunei and Moran et al. (2000) found lower $\mathrm{N}$ in soil solutions and a reduction in $\mathrm{N}$ returned via litterfall fluxes in the same forests. In addition, Fine et al. (2005) found lower mineral N availability in Peruvian HFs. In contrast, Brünig $(1971,1974)$ considers that heath forests are formed due to water limitation which may be especially prevalent on sandy soils.

Examination of $\mathrm{N}$ stable isotopes is a powerful methodology that can assess $\mathrm{N}$ inputs, outputs and transformations in an ecosystem (Martinelli et al. 1999; Robinson 2001; Amundsen et al. 2003); $\mathrm{N}$ availability to plants and trees can be measured by determining stable $\mathrm{N}$ isotope abundance. As an example, tropical rain forest soils and leaves are ${ }^{15} \mathrm{~N}$ enriched compared to temperate forests (Martinelli et al. 1999). The reason for this difference is related to the nature of the greater loss of $\mathrm{N}$ from tropical forests: there is preferential leaching and gaseous loss of the lighter ${ }^{14} \mathrm{~N}$ isotope thereby leaving the soils enriched in ${ }^{15} \mathrm{~N}$. However, another factor which leads to changes in $\delta^{15} \mathrm{~N}$ between soils is a change in moisture regime as a decrease in $\delta^{15} \mathrm{~N}$ with increasing rainfall has been found (Austin and Vitousek 1998; Handley et al. 1999; Schuur and Matson 2001). This is hypothesised to be because of a changing preference for organic forms of $\mathrm{N}$ in wetter soils (Handley et al. 1999).

The aim of this study was to compare $\delta^{15} \mathrm{~N}$ values of soil and plant material from tropical HFs and LERFs and test the null hypothesis of no differences in $\delta^{15} \mathrm{~N}$ signatures and hence minimal differences in $\mathrm{N}$ cycling between the two forest types.

Soil and leaf samples were taken from HF and LERF areas of six tropical sites (Table 1). From four of these sites soils ( 0 $10 \mathrm{~cm}$ ) were collected and from two of the sites leaves of the sub-canopy species Protium subserratum Engl. (Burseraceae) were collected; this species was chosen as it is one of the only species which is common in both HFs and LERFs (Fine et al. 2005).

Samples were analysed for $\delta^{15} \mathrm{~N}$ using a ThermoFinnegan Delta ${ }^{\text {plus }}$ IRMS interfaced with a CE Instruments 1112 Flash elemental analyser via a Conflo III (or a Europa 20-20 IRMS
Table 1 - Locations and rainfall of sites from where soils and leaves were collected for $\delta^{15} \mathrm{~N}$ analysis.

\begin{tabular}{lcc}
\hline Site & Latitude, Longitude & Rainfall \\
\hline $\begin{array}{l}\text { Soils } \\
\text { Bako, Sarawak, } \\
\text { Malaysia }\end{array}$ & $1^{\circ} 43^{\prime} \mathrm{N}, 110^{\circ} 27^{\prime} \mathrm{E}$ & $\begin{array}{c}4048 \mathrm{~mm} \text { (Harrison 2004 } \\
\text { for Kuching) }\end{array}$ \\
$\begin{array}{l}\text { Barito Ulu, } \\
\text { Kalimantan, Indonesia }\end{array}$ & $0^{\circ} 06^{\prime} \mathrm{S}, 114^{\circ} 0^{\prime} \mathrm{E}$ & $\begin{array}{c}3800 \mathrm{~mm} \text { (Brearley et al. } \\
\text { 2007) }\end{array}$ \\
$\begin{array}{l}\text { Kabili-Sepilok, Sabah, } \\
\text { Malaysia }\end{array}$ & $5^{\circ} 52^{\prime} \mathrm{N}, 117^{\circ} 56^{\prime} \mathrm{E}$ & $\begin{array}{c}3000 \mathrm{~mm} \text { (Brearley et al. } \\
\text { 2003) }\end{array}$ \\
\hline $\begin{array}{l}\text { Mabura Hill, Guyana } \\
\text { Leaves }\end{array}$ & $5^{0} 13^{\prime} \mathrm{N}, 58^{\circ} 13^{\prime} \mathrm{W}$ & $2700 \mathrm{~mm}$ (Perreijn 2002) \\
\hline $\begin{array}{l}\text { lquitos, Peru } \\
\text { Rio Blanco, Peru }\end{array}$ & $3^{0} 54^{\prime} \mathrm{S}, 73^{\circ} 31^{\prime} \mathrm{W}$ & $3087 \mathrm{~mm}$ (Marengo 1998) \\
\hline
\end{tabular}

Where LERF and HF sites are separated (e.g. Peru), the location is the mid-point between the two sites.

interfaced with an ANCA-GSL elemental analyser for the Guyana samples). $\mathrm{N}$ isotope ratios are expressed as delta $(\delta)$ notation which is the per mille deviation from atmospheric $\mathrm{N}$ : $\delta^{15} \mathrm{~N}(\% 0)=\left[\left(\mathrm{R}_{\text {sample }} / \mathrm{R}_{\text {standard }}\right)-1\right] \times 1000$ where $\mathrm{R}$ is ${ }^{15} \mathrm{~N} /{ }^{14} \mathrm{~N}$. Precision (standard deviation) of duplicated measurement of sixteen samples on the Delta ${ }^{\text {plus }}$ IRMS was $0.38 \%$.

Soil $\delta^{15} \mathrm{~N}$ values were significantly lower in the HFs when compared with LERF $\left(F_{1,89}=190, p<0.001\right.$; Figure 1a). Leaf $\delta^{15} \mathrm{~N}$ values of Protium subserratum were also significantly lower in the HF when compared with $\operatorname{LERF}\left(F_{1,20}=118, p<\right.$ 0.001 ; Figure $1 \mathrm{~b})$. There was a negative correlation between rainfall at each site and soil $\delta^{15} \mathrm{~N}(r=-0.872)$ although this was not statistically significant $(p=0.128)$.

Numerous studies have shown that a climatic shift of increasing rain fall leads to a decrease in $\delta^{15} \mathrm{~N}$ of soil and/ or foliage (Austin and Vitousek 1998; Handley et al. 1999;

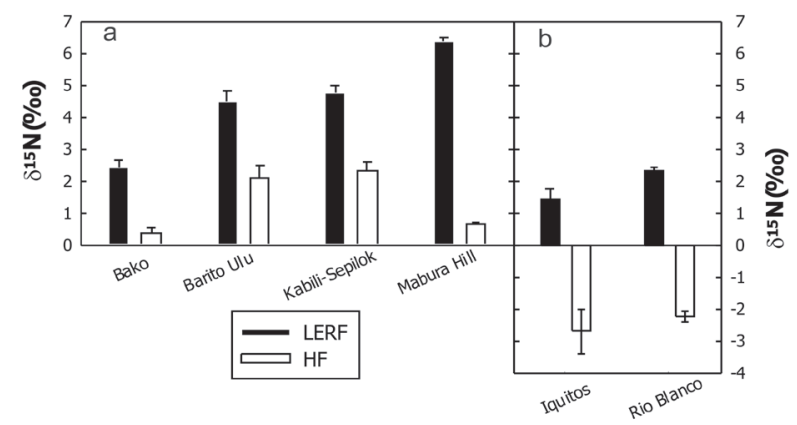

Figure 1 - Nitrogen isotope $\left(\delta^{15} \mathrm{~N}\right)$ values of soils from four tropical sites (a) and leaves (b) from two tropical sites with lowland evergreen rain forests (LERF) and heath forests (HF). Soil type $\left(F_{1.89}=190, p<0.001\right)$, site $\left(F_{3.89}=\right.$ $13.8, p<0.001)$ and the soil type $\mathrm{x}$ site interaction $\left(F_{3,89}=32.7, p<0.001\right)$ all had a significant effect on the soil sample $\delta^{15} \mathrm{~N}$ values. Soil type $\left(F_{1,20}=\right.$ $118, p<0.001)$, but neither site $\left(F_{120}=2.74, p=0.11\right)$ nor the soil type $x$ site interaction $\left(F_{1,20}=0.31, p=0.58\right)$ had a significant effect on the leaf $\delta^{15} \mathrm{~N}$ values. 
Schuur and Matson 2001; Amundsen et al. 2003; Sah et al. 2006) both in temperate and tropical sites. Following this pattern, water limitation would be expected to lead to increases in $\delta^{15} \mathrm{~N}$. If, therefore, tropical HF soils were water limited over LERF soils we would expect an increase in $\delta^{15} \mathrm{~N}$, not the decrease which was actually seen. The change in $\delta^{15} \mathrm{~N}$ values are most likely to result from an altered $\mathrm{N}$ cycle in the HFs and almost certainly from reduced losses of ${ }^{15} \mathrm{~N}$ depleted compounds.

Whilst there are often differences in available soil $\mathrm{N}$ between forest types there has been little evidence for differences in mineralisation rates. Can our isotopic results therefore be reconciled with those of Vernimmen et al. (2007) and Fine et al. (unpublished data) who found minimal differences in $\mathrm{N}$ mineralisation between HF and LERF soils at the Barito Ulu and Iquitos sites respectively? Yes, in so far that for isotopic fractionation to occur, there must be losses of ${ }^{15} \mathrm{~N}$ depleted compounds from soils. This can occur through nitrate leaching or denitrification to nitrous oxide. Indeed, we know that emissions of nitrous oxide can be very high from tropical forest soils (Houlton et al. 2006). At our Guyana study site, Perreijn (2002) found that denitrification rates were lower in HF than LERF and we therefore hypothesised that this, more generally, is the cause of the differences in soil $\delta^{15} \mathrm{~N}$ between the two forest types as suggested by Houlton $e t a l$. (2006) to explain differences in soil $\delta^{15} \mathrm{~N}$ in relation to climate.

This paper therefore suggests that nitrogen availability is more important in controlling the formation of HFs than water availability confirming the results of previous investigators who found little evidence for drought tolerance among HF trees (Becker 1996; Nagy and Proctor 2000; Sobrado 2010). Nagy and Proctor (2000) also showed that foliar $\delta^{13} \mathrm{C}$ values were not different between canopy trees in HF and LERF at Barito Ulu adding further support to our hypothesis that water limitation is not of over-riding importance in leading to the HF formation. We suggest that further examination of $\mathrm{N}$ cycling patterns in both forest types are continued to examine exactly where in this complex cycle differences between the forest types occur. However, whilst ruling out the over-riding importance of water stress it does not rule out that $\mathrm{N}$ cycling may be limited by extreme soil acidity as suggested by Proctor (1999).

\section{ACKNOWLEDGEMENTS}

Funding for this study was provided by the Department of Botany, Trinity College, Dublin. We thank the Guyanese, Indonesian, Malaysian and Peruvian authorities for permission to work and sample in their respective countries. Robert Bagchi and Ronald Vernimmen are thanked for their comments on the manuscript and Alexandra Gabaglia is thanked for the Portuguese translation.

\section{REFERENCES}

Amundsen, R.; Austin, A.T.; Schuur, E.A.G.; Yoo, K.; Matzek, V.; Kendall, K.; Uebersax, A.; Brenner, D.; Baisden, W. T. 2003. Global patterns of the isotopic composition of soil and plant nitrogen. Global Biogeochemical Cycles, 17: Art 1031.

Austin, A.T.; Vitousek, P.M. 1998. Nutrient dynamics on a precipitation gradient in Hawai'i. Oecologia 113: 519-529.

Becker, P. 1996. Sap flow in Bornean heath and dipterocarp forest trees during wet and dry periods. Tree Physiology, 16: 295-299.

Brearley, F.Q.; Press, M.C.; Scholes, J.D. 2003. Nutrients obtained from leaf litter can improve the growth of dipterocarp seedlings. New Phytologist, 160: 101-110.

Brearley, F.Q.; Proctor, J.; Suriantata; Nagy, L.; Dalrymple, G.; Voysey, B.C. 2007. Reproductive phenology over a 10-year period in a lowland evergreen rain forest of central Borneo. Journal of Ecology, 95: 828-839.

Brünig, E.F. 1971. On the ecological significance of drought in the equatorial wet evergreen (rain) forest of Sarawak (Borneo), p. 6696. In: Flenley, J.R. (Ed.). The Water Relations of Malesian Forests: Transactions of the First Aberdeen-Hull Symposium on Malesian Ecology, Miscellaneous Series 11. Department of Geography University of Hull, UK.

Brünig, E.F. 1974. Ecological Studies in the Kerangas Forests of Sarawak and Brunei. Borneo Literature Bureau for Sarawak Forest Department, Kuching, Malaysia.

Fine, P.V.A.; Mesones, I.; Coley, P.D. 2004. Herbivores promote habitat specialization by trees in Amazonian forests. Science, 305: 663-665.

Fine, P.V.A.; Daly, D.C.; Muñoz, G.V.; Mesones, I.; Cameron, K.M. 2005. The contribution of edaphic heterogeneity to the evolution and diversity of Burseraceae trees in the western Amazon. Evolution, 59: 1464-1478.

Handley, L.L.; Austin, A.T.; Robinson, D.; Scrimgeour, C.M.; Raven, J.A.; Heaton, T.H.E.; Schmidt, S.; Stewart, G.R. 1999. The ${ }^{15} \mathrm{~N}$ natural abundance $\left(\delta^{15} \mathrm{~N}\right)$ of ecosystem samples reflects measures of water availability. Australian Journal of Plant Physiology, 26: 185-199.

Harrison, R.D. 2004. A severe drought in Lambir Hills National Park, p. 51-64. In: Roubik, D.W.; Sakai, S.; Hamid Karim, A.A. (Eds.) Pollination Ecology and the Rain Forest: Sarawak Studies, Ecological Studies 174. Springer, New York, USA.

Houlton, B.Z.; Sigman, D.M.; Hedin, L.O. 2006. Isotopic evidence for large gaseous nitrogen losses from tropical rainforests. Proceedings of the National Academy of Sciences of the USA, 103: 8745-8750.

Marengo, J. 1998. Climatología de la zona de Iquitos, Perú, p. 35-57. In: Kalliola, R.; Flores Paitán, S. (Eds.) Geoecología y Desarollo Amazónico: Estudio Integrado de la Zona de Iquitos, Perú. University of Turku Press, Turku, Finland. 
Martinelli, L.A.; Piccolo, M.C.; Townsend, A.R.; Vitousek, P.M.; Cuevas, E.; McDowell, W.; Robertson, G. P.; Santos, O.C.; Treseder, K.K. 1999. Nitrogen stable isotopic composition of leaves and soil: tropical versus temperate forests. Biogeochemistry, 46: 45-65.

Moran, J.A.; Barker, M.G.; Moran, A.J.; Becker, P.; Ross, S.M. 2000. A comparison of the soil water, nutrient status, and litterfall characteristics of tropical heath and mixed-dipterocarp forest sites in Brunei. Biotropica, 32: 2-13.

Nagy, L.; Proctor, J. 2000. Leaf $\delta^{13} \mathrm{C}$ signatures in heath and lowland evergreen rain forest species from Borneo. Journal of Tropical Ecology, 16: 757-761.

Perreijn, K. 2002. Symbiotic Nitrogen Fixation by Leguminous Trees in Tropical Rain Forest in Guyana. Tropenbos-Guyana Series 11. Georgetown, Guyana.

Proctor, J. 1999. Heath forests and acid soils. Botanical Journal of Scotland, 51: 1-14.

Robinson, D. 2001. $\delta^{15} \mathrm{~N}$ as an integrator of the nitrogen cycle. Trends in Ecology and Evolution, 16: 153-162.

Russo, S.E.; Davies, S.J.; King, D.A.; Tan, S. 2005. Soil-related performance variation and distributions of tree species in a Bornean rain forest. Journal of Ecology, 93: 879-889.
Sah, S.P.; Rita, H.; Ilvesniemi, H. 2006. ${ }^{15} \mathrm{~N}$ natural abundance of foliage and soil across boreal forests of Finland. Biogeochemistry, 80: 277-288.

Schuur, E.A.G.; Matson, P.A. 2001. Net primary productivity and nutrient cycling across a mesic to wet precipitation gradient in Hawaiian montane forest. Oecologia, 128: 431-442.

Sobrado, M.A. 2010. Leaf characteristics, wood anatomy and hydraulic properties in tree species from contrasting habitats within upper Rio Negro forests in the Amazon region. Journal of Tropical Ecology, 26: 215-226.

Turner, I.M.; Lucas, P.W.; Becker, P.; Wong, S.C.; Yong, J.W.H.; Choong, M.F.; Tyree, M.T. 2000. Tree leaf form in Brunei: a heath forest and a mixed dipterocarp forest compared. Biotropica, 32: 53-61.

Vernimmen, R.R.E.; Verhoef, H.A.; Verstraten, J.M.; Bruijnzeel, L.A.; Klomp, N.S.; Zoomer, H.R.; Wartenbergh, P.E. 2007. Nitrogen mineralization, nitrification and denitrification potential in contrasting lowland rain forest types in Central Kalimantan, Indonesia. Soil Biology and Biochemistry, 39: 2292-3003.

Recebido em 12/08/2010

Aceito em 13/03/2011 